\title{
ОТРАЖЕНИЕ В ДИАЛЕКТНОЙ ЛЕКСИКЕ КОММУНИКАТИВНЫХ КАЧЕСТВ РЕЧИ (НА ПРИМЕРЕ ГОВОРОВ КРАЙНЕГО СЕВЕРО-ВОСТОКА) ${ }^{1}$
}

\section{REFLECTION IN THE DIALECT VOCABULARY OF THE COMMUNICATIVE QUALITIES OF SPEECH (ON THE EXAMPLE OF THE TALES OF THE HARD NORTH EAST) ${ }^{2}$ N. Sokolyanskaya}

Summary: This article examines the main features of the communicative qualities of speech, reflected in dialect vocabulary, using the example of dialects of the Far North-East. Goal. A complete study of the communicative qualities of speech in the dialectal vocabulary of the Far North-East.

The communicative qualities of speech in the dialectal vocabulary of the Far North-East to a large extent impart an emotional coloring and characteristic expression to the language. The style of such vocabulary demonstrates various aspects that make it possible to instantly assess a person's speech behavior.

The speech dialect system of the Far North-East is unique in its kind, which is characterized by the peculiarities of lexical means that ensure full communication between people. When using dialectal speech, the fullness and expressiveness of the lexicon is preserved, as a result of which the essence of what is said becomes especially bright and meaningful.

Keywords: dialectal vocabulary, speech, communicative qualities, language, speech behavior, linguistic means, communication, lexical unit, semantic field, word formation.

\section{Введение}

$\mathrm{B}$ се социальные отношения людей, все виды их жизнедеятельности охвачены общением. Гармоничные межличностные связи предполагают умение анализировать речевую ситуацию, использовать уместные языковые средства и приемы кооперативного взаимодействия для успешной коммуникации.

Слово способно фиксировать опыт коллектива по наполнению внутренней формы лексической единицы, изучение которой дает возможность понять историю, культуру данного народа, исконный «язы-

\author{
Соколянская Наталья Николаевна \\ к.филол.н., доцент, ФГБОУВО «Северо-Восточный \\ государственный университет» \\ nata_sokol@mail.ru
}

Аннотация: В данной статье рассмотрены основные особенности коммуникативных качеств речи, отраженных в диалектной лексике на примере говоров Крайнего Северо-Востока. Цель. Полноценное изучение коммуникативных качеств речи в диалектной лексике Крайнего Северо-Востока.

Коммуникативные качества речи в диалектной лексике Крайнего СевероВостока в значительной степени придают эмоциональную окраску и характерную выраженность языку. Стиль такой лексики демонстрирует различные аспекты, позволяющие мгновенно оценить речевое поведение человека.

Речевая диалектная система Крайнего Северо-Востока является уникальной в своем роде, что характеризуется особенностями лексических средств, которые обеспечивают полноценную коммуникацию между людьми. При использовании диалектной речи сохраняется наполненность и выразительность лексикона, в результате чего сущность сказанного становится особенно яркой и содержательной.

Ключевые слова: диалектная лексика, речь, коммуникативные качества, язык, речевое поведение, языковые средства, коммуникация, лексическая единица, семантическое поле, словообразование.

ковой характер» в сочетании с тем, «что воспринято языком от характера нации» [Гумбольдт, 1985, с. 373]. Лексические средства, фиксирующие процесс коммуникации, позволяют проанализировать особенности речевого акта, характерные для определенной местности, и обобщить народный опыт понимания людьми друг друга.

Речевая стратегия всегда направлена на достижение определенной коммуникативной задачи и учитывает не только ситуацию, но и аспекты восприятия мира адресатом, его психику (знания, оценки, желания). Идея этичности речи базируется на представлении о моральных цен-

\footnotetext{
\begin{tabular}{|l}
1 Работа выполнена при финансовой поддержке РФФИ, проект 20-012-00266 «Региональные варианты русского языка на \\
Крайнем Северо-Востоке России» \\
$2 \quad$ This work was supported by the Russian Foundation for Basic Research, project 20-012-00266 "Regional variants of the Russian \\
language in the Far North-East of Russia"
\end{tabular}
} 
ностях и представляет оценивание речевого поведения по степени доброжелательности, содержательности, понятности, правдивости, краткости, целесообразности, информативности.

Анализ параметров общения, типов репрезентации формы речевого выражения (темпа речи, силы голоса и др.), оценка собеседника и содержания его высказываний имеет свои особенности в диалектной среде, представляющей специфический языковой социум. Диалектная речь как вербальное средство, с одной стороны, обслуживает процесс коммуникации, с другой - является образовательной платформой для передачи новым поколениям знаний о традициях устного народного общения. Речь как основная структура «сознания диалектной языковой личности» может быть рассмотрена через призму «этической системы», ее исследование интересно и важно с точки зрения «культурологической значимости диалекта» [Юрченко, 2007, с. 93]. Понимание роли диалектов в речевом общении и их значение как «хранителей» своеобразной «национально-языковой» привело к ряду исследований в области коммуникативной структуры «сельского общения», рефлексии «диалектоносителей над речью», анализу социально коммуникативных ролей «традиционно деревенского общения» [Гольдин, 1997, с. 2].

\section{Предмет исследования}

Нами был проанализирован корпус диалектной лексики Крайнего Северо-Востока, отражающей речь русского старожильческого населения Охотского побережья (Охотск, Ямск, Ола, Тауйск), реки Колымы (Походск, Нижнеколымск, Среднеколымск и др.), Гижиги, Марково и др. Эмпирическая база для исследования была сформирована по результатам сплошной выборки из «Словаря региональной лексики Крайнего Северо-Востока России» (около 6 тыс. единиц). Этот лексикографический источник ценен не только с лингвистической, но и с историко-этнографической стороны, поскольку «содержит различные сведения, позволяющие понять характер региональной культуры старожильческого населения северо-восточных областей нашей страны» [Шепилева, 2018. с. 114]. Материалом для сопоставления также послужили данные «Толкового словаря живого великорусского языка» В.И. Даля, «Областного словаря Колымского русского наречия» В.Г. Богораза, «Словаря русских народных говоров» (СРНГ), «Словаря русского языка ХІXVII вв.» и др.

Несмотря на смешение с северными народами, жители упомянутых территорий сохранили русские обычаи, этнокультурные традиции и тип общения, необходимый для эффективной устной коммуникации. При этом точность наименования действий, признаков, лиц свидетельствует об осознании коммуникативной позиции участников общения, учете степени их авторитетности, ситуации разговора.

\section{Аиалектная лексика как система}

Лексико-грамматическое разнообразие охватывает всю коммуникативную сферу. В группу слов с наименованием и оценкой речевого акта, его участников включаются:

- глагольные обозначения (отпенишваться «отнекиваться», ляскать «болтать вздор», раскострыжиться «раздраженно, злобно ответить», стричеть «звать, окликать», расчухать «расслышать, разобрать, понять», хамаярить «говорить, толковать заранее о ещё не совершившемся (например, об удаче на промысле)», гадлиться «насмехаться»);

- именные образования (просмешник «насмешник, шутник», распробранюшка «ссора, брань»);

- признаковые характеристики речевого поведения коммуникантов (посказательный (человек) «хороший рассказчик; человек, знающий много старин и старых сказок», ерестливый («сварливый»), простоязыкий «болтливый», полоротый «рассеянный, невнимательный»);

- наречия, конкретизирующие способ действия (любительно «внимательно, приветливо»).

На системные отношения внутри диалекта указывают следующие явления, зафиксированные в словаре региональной лексики Крайнего Северо-Востока:

1. Наличие словообразовательных гнезд с общим семантическим ядром, объединяющим группу однокоренных слов. Например, сухоба «суета, возня, скандал»; сухор «возня, толчея, шум», сухобиться «возиться, драться, скандалить»: «Они, вишь ли, напились, (в) клубе сухобу подняди, стекло разбили, парнишко-то порезался, так милиционер их (в) Черской увез»; «Напились и сухоботятся топер, сухор поднимают»; «Иван Вострякох, как напьётся, так сухобится, дома покою нету-ка и суседам мешает» [Зотов, 2010, с. 460]. Наличие вариптивных образований именого (сухоба сухор) и глагольного (сухобиться - сухоботиться) характера подтверждают отмеченную 3.M. Богословской избыточность «языкового кода», ведущую к ситуации, когда «количество форм» для отражения семантики в 2 раза «превосходит количество значений» [Богословская, 2006, с. 3].

Деривационная связь отмечается также в словах ереститься «ссориться, браниться» и ерестливый «сварливый, ворчливый»: «Ерестятся между собой, не сходятся, не могут примириться»; «Приезжает и говорит, сто, мама, я зыть там не буду, мать его ерислива, отец пьяница, и он туда зэ» [Зотов, с. 158]. 
2. Синонимические образования: ляскать «болтать вздор», лепетать «говорить вздор»; гаметь «шуметь», гудеть «шуметь, веселиться»; вракун «лживый человек», халя «врун», бахарь «лгун», сослушник «смутьян, врун, сплетник»; враница «ложь», неправка «неправда».

3. Существование антонимических пар: простоязыкий «болтливый» - мольчажливый «молчаливый, скромный».

4. Связанные между собой значения многозначного слова. Например, достаточно широким является семантический диапазон глагола сухобиться «возиться, драться, скандалить». При анализе элементов семной структуры этих глаголов отмечается близость таких элементов, как «производить шум и беспорядочные движения» (возня); «спорить до ссоры» (драться); «ссориться с криками, шумом и дракой» [см. БТСРЯ, 2002].

\section{Отражение в ^ексике раз^ичных сторон коммуникашии}

Лексика, характеризующая диалектную коммуникацию, отражает разные ее аспекты. Стиль поведения при общении может быть отчужденный, демонстрирующий неприязнь и избегание контакта, или, наоборот, дружелюбный, выражающий поддержку и одобрение. Языковая маркировка обычно характерна для лексических единиц с негативной оценкой: отмечается существенный перевес количества слов с отрицательно-оценочной коннотацией, что «соотносится с представлениями диалектоносителей о норме» [Шулякина, 2015, с. 479]. Именно отклонение от нормы номинируется более часто: «норма в принципе одна, отклонений же от нормы может быть сколько угодно» [Арутюнова, 1984, с. 17].

Тематическое поле «доброжелательность»/ «недоброжелательность», «дружелюбие»/ «недружелюбие» характеризует намерения собеседников относительно друг друга: это может быть обоюдное стремление к добру, желание благополучия, расположенность к разговору, симпатия или, наоборот, невежливость, развязность, бесцеремонность одного из коммуникантов. В семантике существительного «куркулей» («нелюдимый, злобный») сочетаются, с одной стороны, замкнутый характер человека, а с другой - его враждебно-агрессивная манера вынужденного общения [Зотов, с. 240]. В Якутии отмечено только одно значение этого диалектизма: «куркулей» - «нелюдимый человек», его негативное характеризующее значение соотносится с неодобрительной семантикой однокоренного слово «куркуль» (разг. жадный, скупой - БТСРЯ) [СРНГ, т. 16, с. 131; БТСРЯ, 2000, c. 482].

Прилагательное «нетоварищный» («неприветливый, необщительный») является отрицательным образованием от слова «товарищный». Его фиксирует словарь XI-XVII вв. в значении «дружеский»: «Имъ [пушкарям и мастерам] доведется... самимъ межъ себя радостнымъ и товарищнымъ обычаемь имбтися. Устав ратных д. II, 4. XVII в.» [вып. 29, с. 381]. В живом диалектном употреблении уточняется значение (ведет себя не как товарищ, не как друг): «Пойдес к нему, там покурить или денег попросить, он сказет - нет, а у самого есть, а если даст - недовольный буват, вот он и нетоварисной целовек» [Зотов, с. 306]. Близкое по смыслу прилагательное «неприбежной» отмечено в русском колымском наречии В.Г. Боргоразом в выражении «неприбежной людям человек» с толкованием «нежелающий обращаться к другим, нелюдимый» [Богораз, 1901, с. 91].

Противоположная коммуникативная ситуация может быть описана с помощью глагольных обозначений «союзиться» («стремиться к общению, к дружбе, сотрудничеству»), «привечать» («радушно встречать, хорошо относиться к кому-либо»), качественного признака «неотказной» («безотказный, доброжелательный»). Фольклорные материалы В.Г. Богораза подтверждают употребление слова «привечать» в этом же значении: «Своего мила дружка я привечала, угощала» [Богораз, 1901, с. 117]. Современная лексикография фиксирует разговорно-сниженный характер этой лексической единицы (привечать/ приветить) при сохранении основной семантики «ласково, приветливо встречать, принимать кого-л.» [Ефремова, 2000, т.2, с.].

Положительная коннотация прилагательного «неотказной» связана еще и с привычкой человека держать свое слово, не отказываться от него: «Целовек твердой, слово дёрзыт, неотказной, гля цево не попроси - фсо зделат гля зителяф» [Зотов, 2010, с. 304].

Выражение глаз также может служить объективацией расположенности к собеседнику. Наречный конкретизатор «любительно» в сочетании с глаголом «смотреть» выражает степень доброжелательности участника речевой ситуации и имеет значение «внимательно, приветливо встречать» [Зотов, с. 257]. Смысловое содержание лексемы связано, скорее всего, со словами «любительный» в дефиниции «приязненный, приятельский, дружелюбный, дружественный» (см. В.И. Даль) и «любо́й» в значении «приятный, угодный» в русском колымском [Даль, т. 2, с. 282; Богораз, 1901, с. 77].

Упрямство как неспособность гибко изменить свое мнение отражено во внутренней структуре глагольного образования «неувещимый»: «В тундру вас не возьмут, холонно, не просите, этот чукча неувещимой» [Зотов, 2010, с. 306]. 
Конфликтные параметры общения отражены в немалочисленной группе слов, воспроизводящих в своем значении ситуацию ссоры, готовность к столкновению мнений, невозможность избежать инцидента.

Лексема «айданить», впервые отмеченная В.Г. Богоразом в значении «вздорить, ссориться», на Колыме благодаря активному употреблению приобретает дополнительные оттенки значения «скандалить, шуметь»: «Ванька Посох айданит, напийса, так казной день, нехоросой, темной он цеавек» (Нижнеколымск, Русское Устье). Именной дериват «айдан» демонстрирует, вопервых, прямое смысловое соответствие исходному глаголу в глагольно-именном сочетании «учинить айдан» (айдан - «шум, скандал, неурядица, суматоха»): «Йезавета Бйохкина айдан уцинийа, не дал бутуйку, сумит, мат допускаэт». Во-вторых, у слова развивается более абстрактное значение «беда, тревога», например в описании народной приметы «Никакие айданы - да не будут, здоровье будет, голод не будет» [Зотов, 2010, с.]. Впервые отмечается возвратное новообразование «айдоваться» («капризничать»), отражающее поведение детей: «Люба айдоваит, плачет» (Походск).

Близкий по семантике глагол «обвздориться» («рассориться, повздорить») выражает, с одной стороны, интенсивность процесса, с другой - его распространенность: «Вот уж год как обвздорился, уехал в Якутск, не пишет, а мать переживает» [Зотов, с.313].

Глаголы речи отражают два плана общения: позицию говорящего, который свое высказывание адресует слушающему, и позицию собеседника, который воспринимает речь. Мы отметили несколько слов, в лексическом значении которых отражена разная степень агрессивности речевых действий по отношению к коммуникативному партнеру: журить («бранить»), оскаляться («сердиться, браниться»), зубатить («грубить, огрызаться»), раскострыжиться («раздраженно, злобно ответить»): «Сероска, не озорницай, дедуска оскаляться будёт»; «С бабуской зубатит, а деда боится, отец его ремнем уцит» [Зотов, с. 166, 193, 331]. Для наименования конфликтного собеседника используется имя существительное оглода («грубиян, отвечающий на просьбы, приказы бранью, неуступчивостью, огрызающийся человек»): «Уступи младсей, оглода, она просит теба» [Там же, с. 319].

Некоторые лексические единицы, именующие коммуникативное поведение носителя диалекта по отношению к участнику разговора, указывают на назойливость, надоедливость партнера, его агрессию: треститься («приставать, цепляться к кому-либо»), цапаться («задираться с кем-либо; возиться»), наянить («нахально приставать, навызываться»), жугай («навязчивый, надоедливый человек, иногда непослушеый (о детях)», ерест- ливый («сварливый, ворчливый»): «Чего-то он mpecmumся наскаковат, чё надо-то ёму»; «Бегат, как жугай, надоел сохсем»; «Юра, что ты с ним цапаешься и цапаешься»; «Ты сто зэ наянис, это гадство, разве она тебе знакомая?»; «Приезжает и говорит, сто, мама, я зыть там не буду, мать его ерислива, отец пьяница, и он туда зэ» [Там же].

Лексемы, репрезентующие способы вербального оформления мыслей, могут учитывать использование силы голоса при говорении. Фактор голоса принимается во внимание в семантике таких глаголов начинательного способа действия, как «заайданить» («зашуметь, поднять крик, шум») и «забазанить» («громко закричать, заговорить, зареветь (о детях)»). В глаголе с видовым противопоставлением «базанить» уточняются количественные параметры интенсивности проявления действия («говорить без умолку, перебивая кого-то»): «Лена, успокой Госку со Светой, сто они там базанят, у нас ведь люди цужие, нехоросо» [Зотов, 2010, с. 57]. По сравнению с общедиалектным словом «базан», которое встречается на всей территории России, колымское существительное «базан» имеет более узкое значение: оно употребляется с семантикой а) «крикун, говорун»; б) «плакса» (и не употребляется для наименования хвастуна) [СРНГ, т. 2, с. 47].

Для влияния на партнера по коммуникации необходимо прогнозировать итоги общения, учитывая механизмы согласования всех его сторон. Анализируемые нами лексические единицы воплощают в какой-то мере нравственные ценности, которые существуют в духовной сфере и являются регулирующими для выбора речевой стратегии. Так, например, этические нормы предписывают, чтобы говорящий был ответственным за содержание своей речи, они помогают оценить такие достоинства речи, как понятность, содержательность, правдивость, краткость, вежливость.

«Коммуникативная группа» диалектной лексики дает нам представление о «допустимости/ недопустимости» некоторых явлений при общении. К примеру, слова, формирующие семантическое поле с общим элементом «ложь, обман», позволяют реконструировать отношение к обману в среде русскоязычного населения Крайнего Северо-Востока. В его речи немало лексических номинаций, включающих сему «относящийся к обману». Причем, как показывают исследования, существует немало видов обмана: «вранье, клевета, притворство, лесть, мошенничество» и т.д. [Кучко, 2017, с. 3]. Лексема «закоснуться» с общеграмматическим значением процесса имеет семантику «соврать», подтвержденную наличием рядом стоящего синонима (закоснулся - заврался): «Опеть ты закоснулся, опеть перебрал слова, заврался» (Зотов, с. 176). Отмеченный В.Г. Богоразом в русском колымском наречии глагол «закоснуть» («захлестнуть») может рассматриваться как производящее слово, на базе которого возникает 
переносное значение. Объединяющей семой выступает фиксация отклонений в пространстве (у Богораза: «Закоснулся узёл, да и развязать немножко») или в речевом поведении («опеть перебрал слова»). Повсеместно также отмечается вариант «обманить» («обмануть»).

Лексические номинации с предметным значением представляют две группы, различающиеся по степени абстрактности. В первую группу вошли названия лиц тех, «кто говорит неправду»: «халя» («врун, озорник»), «сослушанник» («смутьян, врун, сплетник»), «бахарь» («сказочник, болтун, лгун»), «вракун» («лживый человек»). Во вторую группу - относительные существительные «враница» («неправда, ложь»), «неправка» («неправда»).

Очень часто многозначность существительных реализуется как перечень нескольких отрицательных характеристик, связанных друг с другом: врун - озорник; врун - смутьян, сплетник: «Лида, посмотри-ка, что твой (сын) халя делат: стукатурку нозом испортил...»; «О, это Олёха Реброх великой сослусанник, вы его только слусайте...».

Общедиалектное слово «бахарь», дающее человеку наименование в соответствии с коммуникативными талантами и изъянами, фиксируется В значениях «говорун, краснобай», «хвастун», «сказочник», «знахарь» и даже «любовник» [СРНГ, вып. 2, с. 152]. На Колыме также было употребимо глагольное образование «бахарить»/ «бахорить» («рассказывать сказки») [Богораз, 1901, с.22; Зотов, 2010, с. 63]. У существительного «бахарь» здесь отмечается развитие дополнительного значения: «бахарь» («сказочник, болтун, лгун») [Зотов, с.62]. Интересно, что семантика «лгун», объяснимая как формирование негативной коннотации на фоне нейтрального «сказочник», может быть связана с глаголом «бахать» («лгать»), отмеченное в пермских говорах [СРНГ, вып. 2, с. 152].

Заслуживает внимания и активное словообразование при номинации человека, склонного говорить неправду. Общеупотребительный производящий глагол «врать» (в диалектах - «вракать») дает начало большому числу дериватов, номинирующих именно лицо женкого пола: вракуша, вракушка, вракалка («лгунья», ж.р.) [СРНГ, вып. 5, с. 186-187]. И только существительные «вракала», «врала» = «вракала» можно отнести к словам общего рода («лгун, обманщик») [Там же]. На Колыме словопроизводство ведет созданию других элементов этого гнезда. Мы имеем в виду название «вракун» («лживый человек») и «враница» («неправда, ложь»): «Их дет, отец, сын - вракуны, в их семье враница постоянно зывет» [Зотов, с. 105].

Повышенное внимание к содержательности речи отражают такие глаголы, как алясничать «говорить вздор, заговариваться», оллящить «разговаривать попусту, болтать», турусить «говорить вздор, нести чепуху», леnетать «болтать вздор». Интенсивность воздействия на собеседника и значимость диалога могут быть несущественными, если слушающий распознает пустую речь, отнимающую у него время и силы.

Лексема аллясничать связана деривационными отношениями с несколькими однокоренными словами, которые проясняют ее семантическую структуру. Существительное аляс, употребляющееся «как ругательство», зафиксировано еще В.Г. Богоразом в «Областном словаре колымского русского наречия»: «Аляс (айясъ) - бестолковый, придурковатый человек» [Богораз, 1901, с. 19]. Анализ иллюстративного материала подтверждает наличие семы «глупый» в лексическом значении этого слова: «Мелешь, чего сам не толкуешь... Аляс!» [Там же]. В говорах Крайнего Северо-Востока сохраняется бранная коннотация: «Алляс - это дикой маненько, диковатой, дурак. Экой алляс!» [Зотов, 2010, с. 50]. В процесс словообразования вовлечено существительное «алясина», которое в говорах Ярославской области имеет значение «длинный прут, употребляемый вместо кнута», но только в Сибири и на Колыме оно было употребимо еще и в значении «жердь» [СРНГ, вып. 1, с. 249; Зотов, 2010, с. 50]. Именно на этой семантике основано переносное значение, отмеченное в Среднеколымске («перенос., о высоком человеке»): «Оннако он долгой, словно алясина» [Зотов, 2010, с. 50]. В северной диалектной среде было также образовано прилагательное алясный («глупый, бестолковый»): «Госа, перестань, не трогай Светоцку, у, алясной, не понимаш слов-то» (Походск). Таким образом, ряд однокоренных слов, отмеченных в Калужских и Ярославских диалектах, пополняется новыми элементами: «алясина» («жердь») - Якут., Иркутск., Среднеколумск; «аляс» («бестолковый, придурковатый человек») - Колымск., Походск; «алясник» («болтун») - Калужск.; «алясничать» («болтать, врать, рассказывать небылицы, говорить вздор, заговариваться») - Колым., Якут. (Богораз), Калужск., Походск; алясный («глупый, бестолковый») Походск [СРНГ, вып. 1, с. 249].

Вариативной формой к глаголу «ляскать» («болтать вздор») можно считать лексему «олляшить» («разговаривать попусту, болтать»): «Полно ляскать. <...> Баби йаскают, ты не сйусай, музик говойит - бери на ум»; «Ока (Иосиф) олляшит с тобой, а пришёл к отцу по делу, захтра ехать по пастям» [Зотов, 2010, с. 258, 325].

Оценку степени адекватности собеседника и конструктивности обсуждения предмета речи содержит глагол «турусить» («говорить вздор, нести чепуху»): «Ты здря его угостий, топер он будет турусить, а захтра проспится, тогды его мозно на магнитохон...» [Зотов, 2010, с. 479]. В этот синонимический ряд входит и лексема 
«лепетать» в значении «говорить вздор, чепуху»: «Иван Реброх посой, пьеной, йепецет ребетискам - нейзя сйусать» [Там же, с. 248]. Контекстный анализ допускает уточнение толкования слова «лепетать»: очевидно, что в содержании такой речи присутствуют бранные элементы, которые «детишкам нельзя слушать». Слово «бухать» известно в разнообразии своих значения во многих русских говорах, однако с семантикой «болтать вздор» оно было отмечено впервые в Олонецкой губернии в конце XIX века, а затем получило распространение на Колыме. Пословицу «Не расчухашь, да и бухашь» в колымском русском наречии указал В.Г. Богораз, живая диалектная речь подтверждает распространение этого глагола: «Сиди не бухай, выражайся подумав» [Зотов, 2010, c. 81].

Негативную коннотацию содержат и прилагательные простоязыкий «болтливый», мудреный «хитрый, изворотливый», характеризующие участников беседы.

Важным условием для успешной коммуникации является установка на доброжелательность, запрет на унижение и оскорбление человека. Глаголы «союзиться» в значении «стремиться к общению, к дружбе, к сотрудничеству» и «привечать» (радушно встречать, хорошо относиться к кому-либо) отражают как раз такой подход (Зотов, с. 444, 387).

\section{Результаты}

Подводя итоги, прежде всего, стоит заметить, что диалектная лексика Крайнего Северо-Востока является весьма интересным и уникальным отображением языка. Она отличается особенностью своего выражения, которое имеет зависимость от эмоций и нравственных ценностей. Использование такой лексики мгновенным образом окрашивает речевое поведение, делая его особенно выразительным. Это обусловлено, в первую очередь, особенностями речи, с помощью которых человек может выразить собственные мысли с определенной эмоциональной точностью, уместной в тех или иных обстоятельствах. Таким образом, диалектная лексика Крайнего Северо-Востока позволяет в полной мере оценить речевое поведение, исходя из эмоциональности и выраженности используемых лексических единиц.

\section{ЛИТЕРАТУРА}

1. Арутюнова Н.Д. Аксиология в механизмах жизни языка// Проблемы структурной лингвистики 1982. - М. : Наука, 1984. - С. 5-23.

2. Богораз В.Г. Областной словарь колымского русского наречия / Собр. на месте и сост. В.Г. Богораз. - Санкт-Петербург : тип. Имп. Акад. наук, 1901. - 346 с.

3. Богословская 3.М. Диалектная вариантология: лексикологический и лексикографический аспекты: автореферат дис. ... доктора филологических наук $: 10.02 .01$ / Томский государственный университет. - Томск, 2006. - 39 с.

4. БТСРЯ - Большой толковый словарь русского языка / Гл. ред. С.А. Кузнецов. - СПб. : Норинт, 2002. - 1536 с.

5. Гольдин В.Е. Теоретические проблемы коммуникативной диалектологии: автореферат дис. ... доктора филологических наук : 10.02.01 / Саратовский гос. ун-т. - Саратов, 1997. - 52 с.

6. Гумбольдт В. Язык и философия культуры: перевод с немецкого языка/ Вильгельм фон Гумбольдт; сост., общ. ред. и вступит. статьи А.В. Гулыш, Г.В. Рапишвили. - М. : Прогресс, 1985. - 451 с.

7. Даль В.И. Толковый словарь живого великорусского языка : [В 4-х т.] / Владимир Даль. - М. : Рус. яз. - 1978-1980.

8. Ефремова Т.Ф. Новый словарь русского языка. Толково-словообразовательный: Св. 136000 словар. ст., ок. 250000 семант. единиц: [В 2 т.] / Т. Ф. Ефремова. - М. : Рус. яз., 2000. - Т. 2: П-Я. - 1084 с.

9. Зотов Г.В. Словарь региональной лексики Крайнего Северо-Востока России [Текст] : около 6000 слов и выражений / Г.В. Зотов ; под ред. А.А. Соколянского. - Магадан : Северо-Восточный гос. ун-т, 2010. - 539 с.

10. Кучко В.С. Семантико-мотивационное поле «ложь, обман» в языковом пространстве русских народных говоров: автореферат дис. ... кандидата филологических наук :10.02.01 / Уральский федеральный университет имени первого Президента России Б.Н. Ельцина. - Екатеринбург, 2017. - 26 с.

11. Кучко В.С. Семантико-мотивационное поле «ложь, обман» в языковом пространстве русских народных говоров : диссертация на соискание ученой степени кандидата филологических наук : 10.02.01 / В.С. Кучко ; [Место защиты: Уральский федеральный университет им. первого Президента России Б.Н. Ельцина]. — Екатеринбург, 2017. — 339 с.

12. Словарь русского языка XI-XVII вв. / АН СССР, Ин-т рус. яз. ; редкол.: С.Г. Бархударов (отв. ред.) [и др.]. - Москва : Наука, 1975-.

13. СРНГ - Словарь русских народных говоров. Вып. 1- 48. - М., Л., СПб., 1965-2015.

14. Шепилева 0.Е. Крайний Северо-Восток России в аспекте лексикографического описания// Научный диалог. - 2018. - №5. - С. 103-119.

15. Шулякина Ю.С. Оппозиция «добрый, отзывчивый человек»/ «злой, недоброжелательный человек» в говорах ивановской области// Вторые Громовские чтения. Русские народные говоры: прошлое и настоящее / сост. Н.С. Ганцовская. - Кострома, 2015. С. 479-483.

16. Юрченко С.А. Этические представления о речи как базовой ценности в сознании диалектной языковой личности // Известия Волгоградского государственного педагогического университета. Серия: Филологические науки. 2007. - № 5. - С. 93-97. 